\title{
Do international fragmentation of production and the participation in Global Value Chains lead to higher growth rates? ${ }^{1}$
}

Camila do Carmo Hermida ${ }^{2}$

Clésio Lourenço Xavier ${ }^{3}$

Guilherme Jonas Costa da Silva ${ }^{4}$

Resumo: Este artigo desenvolve uma abordagem empírica pioneira sobre a relação entre comércio e crescimento econômico de longo prazo a partir da compreensão das novas configurações de comércio expressas na fragmentação internacional da produção e na formação das Cadeias Globais de Valor. Para tanto, utilizou-se uma nova metodologia de decomposição das exportações brutas em medidas de valor adicionado, desenvolvida por Koopman et al. (2010; 2014), e indicadores estimados a partir de dados provenientes da matriz de insumo-produto global - WIOT. Duas hipóteses gerais foram testadas para uma amostra de 40 países no período de 2003 a 2011 via painel dinâmico (Difference GMM e System GMM). As evidências econométricas apresentadas corroboram a hipótese de que a fragmentação e a participação em CGV asseguram maiores taxas de crescimento para os países, mas também denota que a posição dos países nas CGV se faz relevante: países especializados em atividades a montante em setores de alta tecnologia e serviços tendem a crescer mais que países localizados a montante em setores primários.

Palavras-chave: Fragmentação, Cadeias Globais de Valor, especialização vertical, valor adicionado, crescimento econômico.

Abstract: This paper develops a pioneering empirical approach on the relationship between trade and longrun economic growth from the understanding of the new trade setups expressed in the international fragmentation of production and the formation of Global Value Chains. Therefore, we used a new methodology for decomposition of gross exports in value-added measures, developed by Koopman et al. (2010; 2014), and indicators estimated from data of the global input-output matrix - WIOT. Two general hypotheses were tested for a sample of 40 countries from 2003 to 2011 through a dynamic panel (Difference GMM and System GMM). The econometric evidences presented supports the hypothesis that the fragmentation and participation in GVC ensure higher growth rates for countries, but also denotes that the position of countries in the GVC is relevant: countries specializing in upstream activities in high-tech sectors and services tend to grow faster than countries located upstream in primary sectors.

Key-words: Fragmentation, Global Value Chain, vertical specialization, value added, economic growth.

JEL Code: F02; F14; F43

\section{Área 2 ABEIN - Comércio Internacional, Cadeias Globais de Valor e Internacionalização}

\footnotetext{
${ }^{1}$ Este artigo baseia-se em parte da tese de doutoramento da primeira autora, defendida em fevereiro de 2016 no Programa de Pós-graduação em Economia da Universidade Federa de Uberlândia (UFU).

${ }^{2}$ Pós-doutoranda do Instituto de Economia - UFU. Email: camilachermida@ie.ufu.br A autora agradece à Coordenação de Aperfeiçoamento de Pessoal de Nível Superior - CAPES pelo apoio financeiro recebido para a execução dessa pesquisa (PDSEProcesso 6347-14-2).

${ }^{3}$ Professor do Instituto de Economia - UFU. Pesquisador e Bolsista de Produtividade do CNPq. Email: clesio@ufu.br

${ }^{4}$ Professor do Instituto de Economia - UFU. Tutor do Programa de Educação Tutorial do Instituto de Economia - UFU. Email: guilhermejonas@yahoo.com.br
} 


\section{Introduction}

Globalization and the technological changes that took place at the end of the 20th century, specially, innovations in areas such as information and communication technology (ICT) and transport, have brought remarkable changes in the industrial and commercial paradigm. One of these changes is an intensification of the international fragmentation of production - global geographic dispersion/assembly of components within vertically integrated production processes in several countries.

This fragmentation movement coupled with the technological and managerial innovations of the 1980s and 1990s enabled a global production system, recently known as Global Value Chains (GVC), through which different firms in different parts of the world develop one or more stages of the production, from its conception to its final use. In turn, it has intensified international trade flows, characterized by a considerable increase in the volume of intermediate goods instead of final products. Empirical evidences show, for example, that more than $60 \%$ of world trade - around US $\$ 20$ trillion - is concentrated in intermediate goods and services, $30 \%$ are re-exportation of intermediate inputs, and $80 \%$ are carried out through GVC coordinated by multinational companies (OECD, WTO, UNCTAD, 2013, WTO/ IDEJETRO, 2011).

On the one hand, the economic literature indicates that some countries involved in these GVC, such as China and other countries of East Asia and Eastern Europe, has been benefited with an extension of the scope and processes of technological spillover through the chains (LEMOINE; UNAL-KESENCI, 2004. Several papers suggest that success in terms of export and economic performance is related to its commercial specialization, in which participation in GVC contributes in a decisive way. In this postinternational crisis context and in the face of difficulties for the resumption of growth in several developing countries, the insertion in GVC has often been cited as a new opportunity to promote economic growth. On the other hand, this international movement poses challenges to countries' economic policies, insofar as it has increased the interdependence of their decisions in their business.

Many studies with different theoretical and methodological approaches have been developed from an origin of economic literature with the aim to understand the effects of trade on economic growth. However, the urgency of the GVC has important implications in multiple aspects, which have been neglected by much of this literature: both in the theoretical and methodological sphere. For example, most seminal theoretical contributions assume a traditional notion of horizontal specialization, where countries trade only final goods. Consequently, most empirical analyzes evaluate statistics of gross export flows, without considering that there are foreign content in the exports as a result of the growth of industrial fragmented activities and integrated into GVC.

In the face of such evidence, the present article argues that trade analyzes in the 21 st century cannot be adequately understood if international fragmentation of production and the formation of GVC are not explicitly considered. Although there are already some recent studies on trade flows that empirically incorporate such notes, there is still an empirical gap when it comes to the relationship of these phenomena to economic growth. In addition, it is noted that there is no consensus in the theoretical literature regarding the benefits and the long-term effects associated with them.

Then, the contribution of this article to the literature is to develop an econometric analysis, with the aim of demonstrating the importance of aspects related to the international fragmentation of the production and the insertion in GVC for the countries performance in the recent period. The main questions to be answered are: What is the effect of these phenomena on the economic performance of the countries? Are the specialization at specific stages of the overall production process related and/or impacting economic growth?

In order to do so, it is used a new methodology of mathematical decomposition of gross exports in terms of value added, recently proposed by Koopman et al. (2010, 2014), and in indicators calculated from data of the global Input-Output matrix, named 'World Input-Output Tables' (WIOT). Next, an econometric analysis (Difference GMM and System GMM) for 40 countries is carried out in the period from 2003 to 2011. 
The article is divided into three brief sections plus final considerations. The first one emphasizes theoretical elements that point to new patterns of commercial specialization related to such phenomena and their effects on the economic performance of the countries and brings a review of the works found in the literature, that in an empirical way, try to correlate or present sense of determination between the participation in GVC and growth. The second one denotes the methodological aspects related to the indices calculated in this work and the specification of the estimated models; and, the third presents the main results.

\section{Literature review}

International organizations, in particular the World Trade Organization (WTO) and the Organization for Economic Co-operation and Development (OECD) have recently pointed to the possibility of GVC being a new model of economic development, especially for emerging economies (OECD-WTO, 2012, 2013). Most of its international trade reports have pointed out that an attempt by countries to stimulate the formation of whole sectors within their territory would lead to sub-optimal results in terms of economic performance, in relation to models of industrial expansion through international fragmentation of production, since the costs, the production periods and the barriers to entry into existing global chains have been smaller relative to the establishment of a fully domestic chain (OECD-WTO, 2013).

In the same perspective, Kaminski and $\mathrm{Ng}$ (2001), among others, understand the insertion in global production networks as a way for developing countries to catch up with the developed countries, converging and increasing their income levels. By participating in multinational-led GVC, such economies could reach levels of integration with the global economy by accessing external and diversified markets, benefiting from economies of scale and scope, technological learning and knowledge spillovers. Based on the traditional Ricardian view on trade and growth, these authors argue that countries should specialize in productive activities or "tasks" in the chain where they have comparative advantages in international trade. This path, regardless of the productive structure of the countries, would lead to greater external competitiveness and higher rates of economic growth in the long term (Baldwin, 2013, OECD-WTO, 2013).

However, theoretically there is no consensus in the literature about the impacts of the insertion in GVC on the growth, since there are also evidences of difficulties and risks faced by countries in performing offshoring activities. Kaplinsky and Morris (2002) point out that there is a possibility of regression of the development of countries through insertion in GVC, since the hegemony of the leading firms can "lock-in" the position of subsidiary firms in certain functions that add little value and that give low profitability. When countries tend to specialize only in stringent and low-value added activities in the GVC, national companies, especially small and medium-sized enterprises (SMEs), tend to remain trapped in technologically shallow and unprofitable segments, as learning limits are quickly achieved. Therefore, it can lead to a depletion of the possibilities of economic growth and of improvements in social welfare in the long term (Kawakani and Sturgeon, 2010).

Several other studies ${ }^{5}$ point out how an exported product may require a large volume of intermediary inputs from domestic manufacturers, which in turn require significant intermediate imports used in production, leaving only marginal benefits to exporting economies and value added deficits. Then, paradoxically, there is a discrepancy between where the final products are produced and exported and where most of the value is created and/or captured. If a reduction in domestic production of intermediate products is not offset by an increase in exports or in the consumption of final goods, the final result may be a contraction of the economic income (Dalle et al., 2014).

Gereffi (1999) indicates that the benefits extracted from participation in GVC will depend mainly on the type of governance established in the chain and the capacity of appropriability/cumulativity of knowledge by the national firms in the implementation of a certain stage of the productive process, linked to learning and the technological change. In this context, economic upgrading would be a key element to "move up" in the value chain - from assembly activities that use low-skilled, low-cost labor to more

\footnotetext{
${ }^{5}$ Case studies, such as: Nokia N95 smartphone (Ali-Yrkkõ, et al., 2014), iPod (Linden et al. (2009), Barbie doll (Tempest, 1996), among others.
} 
advanced activities - forms of 'full package' supply (Gereffi et al., 2005). For example, what is perceived in the Asian economies that have been successful in terms of export performance is a technological learning movement, through a process of absorption and transfer of technologies that have allowed such countries to advance in more advanced technology areas, such as electrical machinery, components and computer equipment (Lemoine and Ünal-kesenci, 2004).

Therefore, we note in the literature a second perspective on the GVC that places importance on the role of the technological differences of the countries expressed in different trade specializations, however, giving greater weight to the position along the GVC ('place in the chain') and reducing the importance of the sector dimension. In a fragmented production process, a country can position itself in different productive stages in a value chain of the same sector, which have different technological levels and, consequently, differentiated gains. These steps form a "smile curve" that correlates the magnitude of value added in the GVC with the types of activities developed along the chain (stages of the production chain) (OECD-WTO, 2012).

In this sense, a particular country may be located upstream or downstream. The upstream steps can be characterized by the production of raw materials that add little value and are more at the center of the "smile curve" or also by knowledge assets such as R\&D, brand design and conception, among other preassembly services that add higher value in the productive process. The downstream intermediate stages are those related to the assembly of products and to the provision of services (after sales or customer service). According to the "smile curve," the tips of the chains provide greater added value, since countries are both the holders of upstream inputs and intangibles and the downstream intangible services.

Thus, a country may have a high share of exports of technology-intensive sectors, but participate in a downstream phase of the production chain, which does not ensure much gain, such as assembly activities. Or, on the contrary, it can participate in an upstream phase as a supplier of $R \& D$, with high added value, in productive sectors that are not valued as a higher technology sector. In other words, the fact that a final product is completed and exported in one country does not necessarily mean that the domestic firms of that country are dominating the GVC and adding a large percentage of the total value of that product. This was evidenced, for example, in the classic case of iPods/iPhones, which are finalized in China, but Apple, whose head office is in the United States, manages the entire production chain (Dedrick et al., 2008).

Although these new configurations of international trade are already being extensively explored empirically, especially with the launch of the new international trade databases (global input-output matrices), there is little known work which empirically approach the relationship between fragmentation, GVC and economic growth.

Foster et al. (2012) based on data from the World Input-Output Database (1995 to 2008) indirectly assess the effect of participation in GVC on the economic growth of 40 countries by human capital contained in the GVC in a panel data model with fixed effects. They find a positive and significant correlation between per capita GDP growth and the high skill content of people involved in GVC activities and a negative but not significant relationship between low qualification of work in GVC and growth. Thus, through the degree of qualification of the content of the factors of production (specifically - skilled labor), they demonstrate the importance of activities with greater human capital in GVC for the economic growth.

The UNCTAD report (2013) states that there is a positive and significant correlation between the GDP growth rate and the growth of the participation in GVC for both developed and developing countries, considering two periods: 1990-2000 and 2001-2010 (Using the EORA database (UNCTAD - EORA GVC database), and this correlation is much more evident in the most recent period. Moreover, an analysis for the 30 developing countries which more and less participated in GVC shows a close relationship with GDP growth: the first 30 showed a GDP growth average of 3.3\% between 1990 and 2010, compared to only $0.7 \%$ of the last 30 . Given these results, UNCTAD (2013) states that participation in GVC can contribute to the creation of domestic added value, even when such participation requires an increase in foreign content imported into exports.

Foster et al. (2013) fazem uma ampla avaliação do processo de fragmentação internacional da produção na União Europeia e dedicam uma seção do trabalho para avaliar econometricamente a importância relativa desse processo para o crescimento da renda, do valor adicionado nas exportações e do emprego. Para tanto, eles estimam modelos em painel estático (Efeitos fixos) utilizando a base de dados 
WIOT para o período de 1995 a 2007. Eles consideram tanto a amostra total de 40 países, quanto, apenas os 27 países da União Europeia contidos na base; da mesma forma, estimam modelos contendo apenas a indústria manufatureira e modelos completos com todos os setores da economia.

Foster et al. (2013) make a broad assessment of the process of international fragmentation of production in the European Union and devote a section of the work to econometrically assess the relative importance of this process for income growth, value added in exports growth and employment growth. To do so, they estimate static panel models (Fixed effects) using the WIOT database for the period from 1995 to 2007. They consider both the total sample of 40 countries, and only the 27 European Union countries contained in the database. In the same way, they estimate models containing only the manufacturing industry and complete models with all sectors of the economy.

The authors use as dependent variables: the rate of growth of the real product (output of the matrix by deflated country), the rate of growth of real value added in exports and the rate of growth of the level of employment. They prioritize explanatory variables on the supply side and vary with their application in the different models: growth rate of total factor productivity; rate of capital growth; and human capital (the difference between the growth rate of highly skilled workers and the rate of growth of the less skilled). Besides these, they also use export growth and an index that measures the fragmentation of production (vertical specialization) - variable of interest. The main results found are: international fragmentation of production has shown to be significant and positive for growth - countries engaged in vertical specialization movements seem to experience greater efficiency through the receipt of foreign added value. With respect to employment, the authors found low signs of growth effects for the total sample of countries and industries and a significant and positive effect when considering only the manufacturing industries in the European Union.

\section{Methodological aspects}

2.2 Method of decomposition of exports in value added and Indicators

Given the intensification of the new trade patterns highlighted here, it is understood that analyzing the conventional data of gross exports of final products imposes a growing "error" in trade perceptions, given by a double count, equivalent to intermediate inputs, parts and Components that, according to the GVC, pass repeatedly across the borders of the countries until their final consumption. Therefore, a more realistic analysis of the standard of economic specialization of an economy should not be based on finished goods, since the final product is "made in the world".

Based on this finding, several research groups ${ }^{6}$ have sought to develop more precise mathematical measures of international trade through the use of global input-output matrices, which allow the global tracking of added value throughout the entire production process of a industry; And, consequently, the construction of indices to measure the magnitude of these phenomena.

It was decided to use the export decomposition methodology pioneered by Koopman et al. (2010) and later updated by Koopman et al. (2014) and Wang, Wei and Zhu (2014). It is understood that such a mathematical methodology is the most complete and unified in the literature, as it results in a higher level of export decomposition and, consequently, a more precise calculation of the main value added indexes that characterize the movements of fragmentation and formation of GVC. ${ }^{7}$ For the application of this mathematical structure the algorithms packages named decompr and GVC decomposition in software "R", developed by Quast and Kummritz (2015), were used. These algorithms allow the decomposition at the bilateral and sectoral level of the gross exports of the countries into 16 added value components from the theoretical notes of Koopman et al. (2010, 2014).

\footnotetext{
${ }^{6}$ These groups make up the so-called "value added literature." Among them, Hummels et al. (2001), Koopman et al. (2010, 2014), Daudin et al. (2011), Johnson and Noguera (2012), Timmer et al. (2012, 2014) among others.

${ }^{7}$ In addition, the calculation of these indicators by the method of Koopman et al $(2010,2014)$ surpasses the conceptual and methodological constraints present in previous works, such as the seminal paper by Hummels et al. (2001).
} 
In Koopman et al. $(2010,2014)$ is based on the general foundations of Leontief's matrix $(1936)^{8}$, whereby the product of one country can be consumed directly or indirectly used as input by another industry to be consumed or exported as either the final product or Intermediate product. In other words, since an inter-industry and inter-industry analytical framework is used, the matrix of technical coefficients, also called inverse Leontief, is used.

Considering a number $G$ of countries and $N$ of sectors ${ }^{9}$ and defining $\mathrm{r}$, s and $\mathrm{t}$ as three distinct countries, we have: a vector line $1 * \mathrm{~N}, \boldsymbol{V}_{\boldsymbol{s}}$, which represents the coefficient of direct value added for the country s; And matrices A and B that are GN * GN and describe the interrelationships between industries and countries. Where $\boldsymbol{A}_{\boldsymbol{s} r}$ : is an array of technical coefficients $\mathrm{N} * \mathrm{~N}$ ( $\mathrm{N}$ : number of industries) and represents the ratio of inputs from domestic industry s used for production in industry/sector of country $r$. $\boldsymbol{B}_{\boldsymbol{s} \boldsymbol{r}}$ : is $(I-A)^{-1}$ is the inverse matrix of Leontief, which is the sum of the gross product in the country $s$ required to generate an increase of one unit in the final demand in country $r$.

In addition, we consider a vector $\mathrm{N}^{*} 1, \boldsymbol{X}_{\boldsymbol{s} r}$, which describes the total product generated by $\mathrm{s}$ and absorbed by r, where $\boldsymbol{X}_{\boldsymbol{s}}=\sum_{r}^{G} X_{s r}$; And, a vector $\mathrm{N}^{*} 1, \boldsymbol{Y}_{\boldsymbol{s} r}$, which reflects the final products generated by $\mathrm{s}$ and consumed in $\mathrm{r}$, where $\boldsymbol{Y}_{\boldsymbol{s}}=\sum_{r}^{G} Y_{s r}$, i.e. is the sum of the global use of final goods produced by $s$. Defining $\boldsymbol{u}$ as a unit vector $1 * \mathrm{~N}$ and $\boldsymbol{E}_{\boldsymbol{s}^{*}}$ as the country's gross exports to the world, we have the structure of gross exports completely decomposed into nine categories of added value and double counting:

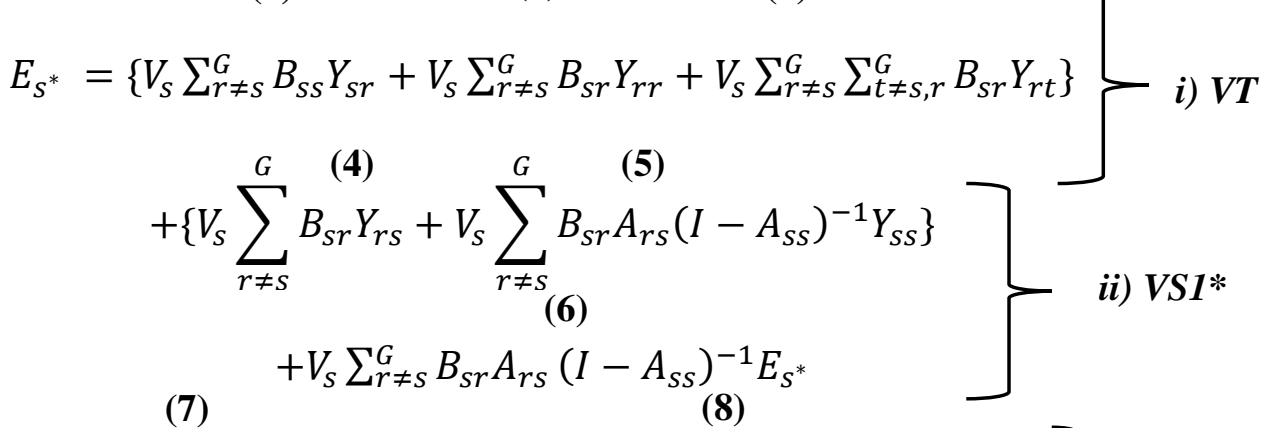

$$
\begin{aligned}
& \left.\begin{array}{c}
+\left\{\sum_{t \neq s}^{G} \sum_{r \neq s}^{G} V_{t} B_{t s} Y_{s r}+\sum_{t \neq s}^{G} \sum_{r \neq s}^{G} V_{t} B_{t s} A_{s r}\left(I-A_{r r}\right)^{-1} Y_{r r}\right\} \\
+\sum_{t \neq s}^{G} V_{t} B_{t s} A_{s r} \sum_{r \neq s}^{G}\left(I-A_{r r}\right)^{-1} E_{r^{*}}
\end{array}\right\} \text { iii) } \mathbf{V S}
\end{aligned}
$$

i) The first group of equations, named by Koopman et al. (2010) of VT, refers to the sum of the value added by a given supplying country, s, which is consumed or used as input at each final destination. This group, in turn, can be decomposed into 3 subgroups: (1) domestic added value (VAD) in order to meet the final demand; (2) VADs in intermediate products which are absorbed directly by the importing country, ie intended for assembly and subsequent absorption by domestic demand of the importing country; And (3) VAD in intermediate products which is exported to one country and then re-exported to third countries.

ii) The second group refers to that part of the domestic value added that is first exported, but which returns to the country of origin. In the literature, this measure was named by Daudin et al. (2011), of VS1*. VS1* is also conceptually decomposed into 3 subdivisions: (4) VAD that is initially exported via intermediate products, but returns to the country of origin through imports of final products, ie to meet final demand; (5) VAD in intermediates that returns via imports of intermediate products for processing or

\footnotetext{
${ }^{8}$ Leontief, W. (1936) “Quantitative Input and Output Relations in the Economic System of the United States”, The Review of Economic and Statistics, Vol. 18, pp.105-25.

${ }^{9}$ In Koopman et al. $(2010,2014)$ it is possible to find detailed information on the entire export decomposition process, with the presentation of a simpler preliminary mathematical structure (with the hypothesis of only two countries) and very illustrative numerical examples. For the purpose of this article, the main points of the development of the general case, that is, for an arbitrary number of countries and sectors, will be presented directly.
} 
assembly phases and subsequent internal absorption; And (6) "pure double counting" - a part referring to domestic exports of intermediaries that cross the border more than twice and do not contribute to the country's GDP because they have already been accounted for in other components.

Due to the presence of this double counting component in a country's gross exports, Koopman et al. (2010) define the domestic value added in exports (DV) as the sum of equations (1) to (5), which is the domestic part that actually contributes to the GDP of the country of origin.

iii) The third group is formed by foreign content or foreign added value (FVA) ${ }^{10}$ in exports. Named, originally by Hummels et al. (2001) of VS index, this measure shows the share of imports of a particular country that is formed by intermediary products and that is not destined to meet the final domestic demand. That is, it comprises imports directly and indirectly incorporated in a country's exports. In this way, it is also interpreted as a measure of the extent of vertical specialization of the country - where a country's exports are dependent on imported content (inputs, parts and components that are produced externally). This index can also be broken down into three categories: (7) VAS of final products (or intended to meet final demand from importing countries); (8) FVA of intermediate products (or intended to meet intermediate demand for later absorption); And (9) what the literature calls the "double counting" of externally produced intermediary products ${ }^{11}$ - the share of foreign intermediate exports crossing the border more than twice before being embedded in the consumption of final products (Koopman et al. 2014).

These indicators can be calculated by destination and disaggregated by sector, allowing on the one hand to understand which (and to what extent) countries are integrated, and, on the other hand, to map where added value was created. In other words, they allow the sector to contribute to the national content of exports. Although it presents the same logic of calculation at the aggregate level, the sectoral calculation of domestic value added in exports (DV) is relatively more complex mathematically, insofar as the domestic backwards linkages are considered in the matrix, that is, it is assumed that a sector Household can add value to exports from another domestic sector and therefore should be calculated in matrix language ${ }^{12}$.

The VS and DV indicators are a methodological advance in the way of evaluating commercial specialization patterns within the context of production fragmentation. The VS index as export ratio is widely used by the value added literature as a measure of the countries' vertical specialization degree and often referred to as a participation rate in the GVC. However, when measured in isolation, it provides an incomplete picture of the countries' involvement in the GCS, especially when the participating countries are located at the beginning of the value chain (upstream - exporters of gross products and intangible goods) and therefore have A lower FVA by definition. In other words, FVA's ratio to gross exports only measures the importance of foreign suppliers in a country's value chain (imported foreign content), however, the same country may also participate in the GVC as a supplier of inputs to third countries, Which process / assemble and future re-export ${ }^{13}$.

Hummels et al. (2001) already pointed out the importance of measuring also the insertion of the upstream countries in the GVC. They called this VS1 measure, which accurately comprises the domestic content of a particular country present in third country exports, but only in Koopman et al. (2010) is the mathematical formalization of this measure, expressed as:

$$
V S 1_{s}=V_{s} \sum_{r \neq s}^{G} \sum_{t \neq s, r}^{G} B_{s r} Y_{r t}+V_{s} \sum_{r \neq s}^{G} \sum_{t \neq s, r}^{G} B_{s r} A_{r t} X_{t}+V_{s} \sum_{r \neq s}^{G} B_{s r} Y_{r s}+V_{s} \sum_{r \neq s}^{G} B_{s r} A_{r s} X_{s}
$$

\footnotetext{
${ }^{10}$ The indicator is also called imported content or embedded imports (II) (OECD-WTO, 2012), and VS by Hummels et al. (2001) and Koopman et al. (2014).

11 Similar to the concept of "pure double counting" in household intermediates, described above. The sum of (6) and (9) is equivalent to the total "double counting" in trade statistics and does not contribute to the GDP of the respective countries, since they were already counted as domestic or foreign exports at an earlier time.

12 For more information on the sectoral mathematical calculation of DV value added measures, see Koopman et al. (2010).

${ }^{13}$ Hummels et al. (2001) identify the percentage of exported products and services used as inputs imported by other countries for subsequent export of the total exported and denominates VS1 share.
} 
Equation (10) shows that VS1 is formed by the sum of four terms: 1) VAD used for the production of final products exported by other countries; 2) VAD used for the production of intermediate goods exported by other countries; 3) VAD that returns to the country of origin via imports of final products; And, 4) VAD that returns via imports from intermediaries (including still the share of "pure double counting").

In order to obtain a more precise indicator of GVC insertion, Koopmann et al. $(2010,2014)$ developed a new GVC participation rate, which was also calculated in this article based on the calculation of the indicators described above. This index takes this multi-stage process into account and combines the VS and VS1 indicators:

$$
G V C_{-} \text {participation }_{s i}=\frac{V S_{s i}}{E_{S}}+\frac{V S 1_{s i}}{E_{S}}
$$

The first term of this equation refers to FVA in exports of sector i of the country s as a ratio of the total exported by the country. It is also referred to in the "backward" participation literature in GVC (backward participation). The second term refers to the VAD in the exports of sector $i$ of the country s that is used in the exports of other countries as a ratio of the total exported by the country s; Called "forward participation" in the chain.

An index was also calculated to capture the position of the countries along GVC, called GVC position, as in Koopman et al. (2010; 2014):

$$
G V_{-} \text {position }_{s i}=\operatorname{Ln}\left(1+\frac{V S 1_{s i}}{X_{s i}}\right)-\operatorname{Ln}\left(1+\frac{V S_{s i}}{X_{s i}}\right)
$$

It is known that at global level VS1 and VS are the same because the export of intermediaries from one country through other countries corresponds exactly to the foreign added value in the exports of another country. Therefore, the calculation of the world average of this indicator is equal to the unit and the interpretation regarding the position of the countries is based on this average:

$G V C_{\text {Position }_{S i}}>1$ : Country s is located upstream in GVC of industry i, providing intermediary goods and services to other exporting countries.

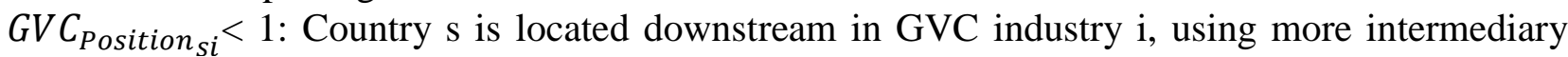
inputs from other countries to generate its exports.

It is worth noting, in aggregate, that this index is an imperfect measure of the positioning of the countries in the GVC, since it does not reveal the sector specificities. For example, the higher the index, the more upstream the country is in the GVC, but it may either be supplying raw inputs (raw materials) or high-tech intermediates or knowledge-intensive services needed for export from third countries.

Given the importance of some theoretical approaches to the technological aspects of the country's trade specialization, it was also decided to use a proxy, here called "q", to measure the sophistication of the export agenda. Taking into account the limitations already mentioned in relation to gross export statistics in the context of GVC participation, the q index is a measure of the relative composition between domestic value added in exports of primary and low technology manufactures and value added In manufactures with higher technological content (medium and medium-high technology). The calculation of the index q was based on the following formula:

$$
q_{s t}=\frac{D V_{2}-D V_{1}}{D V_{T O T A L}}
$$

Where: $D V_{1}$ : Domestic value added exported by the country $\mathrm{s}$ in period $\mathrm{t}$ in primary sectors (commodities, natural resources plus low technology sectors). This portion is interpreted here as the agenda with the lowest technological intensity. $D V_{2}$ : VAD exported by the country $\mathrm{s}$ in period $\mathrm{t}$ in medium and high technology sectors-more dynamic trade. $D V_{T O T A L}$ : is the total VAD of primary and manufacturing sectors by the 
country $\mathrm{s}$ in its own exports. Being $-1 \leq q_{s t} \leq 1$. That is, the closer to 1 , the more dynamic the country's export agenda is and the closer to -1 , the less dynamic the tariff is.

\subsection{Specification of estimated models, variables, and data sources}

The calculation of the aforementioned indicators, as well as the estimation of the econometric models of growth, were made based on the data provided by the World Input-Output Tables - WIOT global input matrix, which belongs to the World Input-Output Database (WIOD), launched in 2012 and Updated in 2014 as an initiative of the European Commission. The choice of this basis is justified for three reasons: 1) the database provides data for an uninterrupted 17-year time series (1995-2011), unlike other bases such as Trade in Value Added (TiVA) launched in 2013 by the WTO In partnership with the OECD which only has data for certain years; 2) WIOT provides the fundamental matrices by which it is possible to replicate a more sophisticated gross export decomposition structure in added heat measurements, as developed by Koopman et al. (2014), as well as the calculation of the indicators mentioned above; 3) the database has more methodologically more consistent and higher quality data than the other global matrices released, since it uses data from use and destination tables (SUTs) instead of IO tables to define the bases of the matrices. This ensures a higher level of data quality compared to other bases such as the GTAP, for example, which includes unofficial statistics to cover a good part of the sample of the countries, or as EORA that relies heavily on imputation methods and weighting to fill The blank fields of the large sample of countries. According to Timmer et al. (2014), this is important because the use of SUTs as basic building blocks allows harmonization with the National Accounts (SEAs) ${ }^{14}$. National Accounts totals are used as reference for the years where SUTs are available and to estimate SUTs when there are missing periods (TIMMER et al., 2014).

The WIOT matrix presents data for 35 industries based on a compatibility of the ISIC (Classification of All Economic Activities - Rev. 3) classification ${ }^{15}$, and for a sample of 40 countries: Austria, Belgium, Bulgaria, Cyprus, Denmark, Spain, Estonia, Finland, France, Greece, Holland, Hungary, England, Ireland, Italy, Lithuania, Latvia, Luxembourg, Malta, Poland, Portugal, Czech Republic, Slovak Republic, Russia, Romania, Sweden, Brazil, Mexico, Canada, United States, Australia, China, South Korea, India, Indonesia, Japan, Taiwan and Turkey. Although the sample appears to be small, it covers the world's largest economies and accounts for more than $85 \%$ of world GDP, which supports its relevance (TIMMER et al., 2012c).

For the construction of the data panels, the analysis period from 2003 to 2011 was selected, for four reasons: 1) Empirical evidence highlighted in the GVC literature emphasizes that they occur more prominently from the 2000s; 2) The end of the 1990s is marked by many crises that hit, to a large extent, the sample of selected countries, especially in relation to external vulnerability (Mexico crisis - 1995, Asian financial crisis 1997-1998, crisis Russia and Brazil (1998); 3) In 2002, there were two macroeconomic events with significant effects that could compromise the reliability of the results: the first is China's entry into the WTO, which affected not only its own external trade insertion but also other sample countries; And the second is the consolidation of the European Union through the adoption of the single currency, the Euro, which also incorporates volatility in the sample, which comprises 27 countries of the European Union; (Cross-section dimension) for a small number of years (time dimension $T$ ), with $T \geq 5^{16}$. This prevents, for example, the use of averages for quinquennia or quadrienians in the total period from 1995 to 2011, which would eliminate fluctuations in income growth.

\footnotetext{
${ }^{14}$ They describe the domestic interactions between the industries themselves and between them and the final demand (families, non-profit organizations, government, investment and exports). For more on concepts and methods of matrix construction, see the manual developed by Timmer et al. (2014).

${ }^{15}$ Full list of industries in Timmer et al. (2014). In order to classify the 35 ISIC (Revision 3) sectors according to technological aspects, the OECD classification (1994) was used. That is to say, they were excluded from the calculation of the technological sophistication index q the services sectors, due to the difficulty of establishing with confidence a technological classification for them at this level of aggregation.

${ }^{16}$ Roodman (2009) and the authors of the panel models suggest the need to have a minimum of 5 observations per country for the model to be reliable and for which important tests such as RA (2) can be calculated.
} 
To estimate how the fragmentation and participation in GVC of the countries are correlated with the economic performance, we chose to use the methodology of data in dynamic panel, through the Method of Generalized Moments (GMM), namely: Difference GMM and System GMM, developed in the works of Arellano and Bond (1991), Arellano and Bover (1995) and Blundell and Bover (1998). It is considered as one of the advantages of the panel data methodology, specifically of the dynamic panels, to allow a more accurate understanding of the dynamic relationships among the variables, which often have a strong correlation with their past values. For such, these models are characterized by the presence of the lagged dependent variable among the regressors and because they treat all explanatory variables as endogenous, including the lagged variable itself. That is to say, this allows the provision of unbiased estimators, unlike static panel models, where bias occurs in the estimated coefficients when including lagged dependent variables.

The Arellano and Bond (1991) estimator of the Generalized Moments Method (GMM) instrumentalizes the explanatory variables in difference that are not strictly exogenous with their available lags in the level. However, in this first difference GMM (Difference GMM) estimator, the available level gaps can be weak instruments for non-strictly exogenous variables if these gaps can be characterized as a random walk. Thus, the development of the System GMM, by Arellano and Bover (1995) and Blundell and Bond (1998), increases efficiency by adding to Difference GMM, the original equation in level, due to the presence of more instruments, being that in equation In difference, the variables are instrumented with their available lags in level, whereas in the level equation the level variables are instrumented with adequate lags of their own first differences. In addition, the differences of the instrumentalized variables are not correlated with the fixed effects.

As a formal mathematical model of economic growth will not be developed here with our variables of interest, it has been chosen to show that they are growth-relevant variables, regardless of the type of theoretical approach or the line of models adopted (models of supply and Models of demand). It is worth mentioning the main hypotheses to be tested:

Hypothesis 1: based on the assertions of international bodies, strongly based on traditional approaches to trade that ensure dynamic gains for all countries involved in trade through comparative advantages: increased participation of the country in international trade, especially through international fragmentation of trade Production and via participation in the GVC assures gains of competitiveness and a better performance in terms of economic growth. It is expected that the greater the vertical specialization and the greater the integration of countries into the global chains, the higher their growth rates.

Hypothesis 2: the pattern of trade specialization associated with GVC positioning matters for economic growth, that is, the success in terms of economic performance of GVC countries' participation is correlated with the location (stage) where the country is in the GVC together with the level of sophistication of its export agenda. Countries that specialize in upstream (upstream) positions in medium-high technology sectors and services in the GVCs of these sectors (by definition: patent, R \& D and design holders) are expected to benefit more from GVC entry and, Therefore, they present higher rates of growth. On the other hand, it is also expected that more sophisticated export patterns or with greater participation of the industry, regardless of their position in the GVC, positively impact the economic performance of the countries; That is to say, it is based on the thesis defended by the Keynesian-structuralist and Neoschumpeterian models on the significant and positive effect of the pattern of commercial specialization in more dynamic industrial sectors for the economic growth of the countries.

Thus, a general model of growth determination is assumed, in which a series of supply and demand variables are combined, which will be the control variables: a measure of the physical capital or investment factor $\left(k_{i t}\right)$, A measure of the labor factor given by the population proxy $\left(l_{i t}\right)$, human capital $\left(c h_{i t}\right)$, institutions ( $\left.i n s t_{i t}\right)$, government spending $\left(g_{i t}\right)$, inflation $\left(i n f l_{i t}\right)$ and trade $\left(e_{i t}\right)$. In addition to this, other variables consecrated by the growth literature as variables of control were included: growth rate of lagged income $\left(y_{i t-1}\right)$ and the initial per capita GDP ( initial $_{i t}$ first year of the analyzed period $){ }^{17}$.

In this general model our variables of interest $\left(X_{i t}\right)$, will be included individually, which are several proxies related to the two hypotheses mentioned: vertical specialization index (or fragmentation of

\footnotetext{
${ }^{17}$ See Table 1 of the Appendix for the list of variables, nomenclature and data source.
} 
production), participation in GVC, positioning in GVC, The degree of sophistication of the export agenda, the participation of the industry in exports and the positioning associated to the sectorial technological degree.

The idea, then, is not to understand the determinants of growth, but to check the relative importance of new international trade configurations, as well as the changes they make in the way countries specialize and compete in GVC, and show that they need Be incorporated into econometric growth models, especially when considered in the most recent context. The following equation describes the general model of estimated economic growth, through which the variables of interest will be inserted:

General Model:

$$
\begin{gathered}
y_{i t}=\propto+\beta_{1} y_{i t-1}+\beta_{2} \text { yinitial }_{i t}+\beta_{3} k_{i t}+\beta_{4} l_{i t}+\beta_{5} \text { ch }_{i t}+\beta_{6} \text { inst }_{i t}+\beta_{7} g_{i t} \\
+\beta_{8} e_{i t}+\beta_{9} \text { infl }_{i t}+\beta_{10} X_{i t}+\mu_{t}+v_{i t}
\end{gathered}
$$

Where: $i=1,2 \ldots . ., 40$ (countries); $t=1,2,3$ (year); $y_{i t}=$ real per capita GDP growth rate and $X_{i t}=$ refers to the variables of interest (calculated indicators) that will be included separately in the general model in order to test the two hypotheses highlighted in the introduction of this article. Thus, $\mathrm{X}$ will define the different models, numbered as follows:

Model 1: Effects of international fragmentation of production: $X=V S_{i t}=$ vertical specialization index VS as a percentage of total exported. It is expected that the greater the vertical specialization of countries, the higher their rate of economic growth.

Model 2: Effects of GVC participation: $X=\llbracket X=G V C \_$participation $_{i t}=$ GVC participation index, calculated based on Koopman et al. (2010). A positive relationship between GVC participation and economic growth is expected.

Model 3: Effects of the position in the GVC (specialization in stages): $X=G V C \_p o s i t i o n_{i t}=$ position index in the GVC. At the aggregate level, this index provides an imperfect view of the countries' positions in GVC because a country can participate "forward" by providing both raw materials and high sophistication services to be re-exported. Countries specializing in primary products and natural resources tend to have a greater "forward" participation in GVC compared to countries specialized in labor-intensive or intensive activities in high-tech manufactures. In this case, the VS1 index tends to be higher than the VS, leading methodologically to higher GVC_position indexes. Thus, it is expected that this index will negatively impact the economic growth of the countries.

Model 4: Effects of industry share of total exported: $X=V A D_{\text {INDUSTRY }} / V A D_{\text {TOTAL }}=$ share of domestic value added by industry over total domestic value added. The post-Keynesian / Kaldorian and Neoschumpeterian literature on economic growth assumes that the industrial sector can attribute greater dynamic effects compared to other sectors (agriculture and services), due to technological advances and innovations, gains in scale and productivity, Factors of production, effects of technological spillovers, etc. Thus, it is expected that the greater the external insertion from industrial sectors (domestic added value in relation to the total domestically produced), the greater the growth of economies.

Modelo 5: Efeitos do grau de sofisticação da pauta exportadora: $q=$ índice de 'qualidade' ou de sofisticação da pauta de exportações (padrão de especialização de acordo com o conteúdo tecnológico). Da mesma forma que no modelo 4, conforme os modelos de crescimento neoschumpeterianos e kaldorianos tradicionalmente apontam, o que um país exporta determina sua taxa de crescimento (países que exportam produtos de maior conteúdo tecnológico ou com maiores elasticidades-renda da demanda crescem mais), portanto espera-se um sinal positivo.

Para avaliar o padrão de especialização em termos tecnológicos em conjunto com a especialização em estágios das GVC, será calculado também mais três proxys distintas: o posicionamento em GVC de baixa tecnologia; de média-alta tecnologia; e em setores de serviços. Acredita-se que uma melhor especialização comercial, no sentido de prover maiores ganhos em termos de crescimento econômico, é caracterizada por uma especialização conjunta em setores de alto teor tecnológico com posições mais a 
montante nas GVC, em função da maior criação de valor adicionado doméstico nas exportações em relação ao conteúdo importado nesses setores.

Modelo 6: $X=G V C_{\text {position_BTt }}$ Posições em setores de baixa tecnologia (primários mais manufaturas de baixa tecnologia). Quanto maior o índice, mais a montante os países estão localizados em setores de baixa tecnologia, fornecendo insumos brutos ou matérias-primas com baixo nível de processamento para serem reexportados pelo país importador, o que por hipótese afeta negativamente o crescimento econômico.

Model 5: Effects of the degree of sophistication of the export agenda: $q=$ index of 'quality' or sophistication of the export agenda (standard of specialization according to the technological content). As in model 4, as the Neoschumpeterian and Kaldorian growth models traditionally point out, what a country exports determines its growth rate (countries that export products with higher technological content or with higher demand elasticities grow more). Therefore a positive signal is expected.

In order to evaluate the technological specialization standard in conjunction with the specialization in GVC stages, we will also calculate three different proxies: the positioning in GVC of low technology; Of medium-high technology; And service sectors. It is believed that a better commercial specialization, in order to provide greater gains in terms of economic growth, is characterized by a joint specialization in sectors of high technological content with positions upstream in the GVC, due to the higher creation of domestic value added Exports in relation to imported content in these sectors.

Model 6: $X=G V C_{\text {position_HTt }}=$ Positions in low technology sectors (primary plus low technology manufactures). The higher the index, the more upstream countries are located in low-tech sectors, providing raw inputs or raw materials with low processing levels to be re-exported by the importing country, which by hypothesis negatively affects economic growth.

Model 7: $X=G V C_{\text {position_HTt }}=$ Positions in high-tech sectors. The higher the index, the more upstream countries are located in high technology sectors, supplying parts and components with high technological content ( $\& \& D$, design, etc.) to be re-exported by the importing country, which by hypothesis indicates higher GDP growth per capita.

Model 8: $X=G V C_{\text {position_st }}=$ Positions in services sectors ("smiling curve" tips). The higher the index, the more upstream countries are located in service sectors, providing pre-assembly or post-assembly services. It is expected that this index will be positively correlated with income growth, since there are several activities of high added value in the chains, such as product differentiation and customization and production control ( $R \& D$, design, projects, specialized technical services, ICT, customized software, branding, marketing, etc.).

\section{Analysis of Results}

In order to assess whether there is a direct correlation between the variables of interest and the per capita GDP growth rate, Figure I (in the appendix) presents different graphs with such correlations for all 40 countries in the sample, Annually in the period 2003-2011 (panel). In most graphs, correlations are not obvious and easy to identify. The GVC positioning indexes associated with the service sector and the medium-high technology category (GVC_positionS and GVC_positionHT respectively), whose positive relation with growth is more noticeable for the sample, and the associated GVC_positionLT index To lowtech sectors that have shown a negative correlation with economic growth. As expected and confirming the UNCTAD (2013) notes, the correlation coefficient calculation denotes a positive relationship between the vertical specialization index, or international production fragmentation (VS) and the GVC_participation index with the per capita GDP growth rate . 
On the other side, contrary to the expected relationship, we have: the GVC_position index, which presented a positive relation with income growth; And the indices q (sophistication of the export agenda) and VAD_industry\% (participation of the manufacturing industry) that show the same negative correlation with GDP growth. In other words, the latter two indexes show a high correlation between each other (approximately equal to unity), which was already expected, since they are distinct proxies for the same standard object of commercial specialization in more dynamic sectors.

These correlations already help to accept at least part of the hypotheses raised in this article, however, due to the endogeneity and omission of variables present in this type of analysis, a more formal test is necessary, which identifies the causal effect (and not the mere Correlation) between these variables and GDP growth, considering all the correlations or cross-effects between these variables and controlling the other factors that affect them.

The results of the estimations of the econometric models of growth in the period 2003-2011, based on equation 14 and through Difference GMM and System GMM, are systematized in table II in the appendix ${ }^{18}$, through which it is possible to evaluate the signal, the statistical significance, the magnitude of the different estimated coefficients and the tests performed (second-order autocorrelation and validity of the instruments). In this case, the data for 40 countries (n) were used for a period of 9 years (T), providing a total of 360 observations. The panel is unbalanced due to the lack of data for some variables in some years ${ }^{19}$.

The Arellano-Bond AR (2) tests presented the expected result in all models of both estimates, therefore, the null hypothesis of absence of second-order serial correlation is accepted and the estimates are confirmed to be consistent. Both instrument validity tests, Hansen test and Difference-Hansen, also presented a high p-value in the two estimates, that is, the null hypothesis of the tests should be accepted: the instruments are valid and not correlated with the error term Of the equation and the endogeneity bias was eliminated - with the exception of the Hansen test for model 6, estimated by Difference GMM at 1\%, but does not reject the hypothesis of validity of the instruments when considering the level of significance of 5\% and $10 \%$ And for model 5 (via System GMM), significant at 10\%. It should also be noted that although the robust Hansen test was weakened in some cases in the estimation by GMM-System given the high number of instruments, it presented a plausible p-value of less than 1 , so the validity of the instruments did not was affected ${ }^{20}$.

Although model estimates are presented by means of the two methods for comparison purposes, the most appropriate results refer to the GMM-System method, since the Hansen Difference test presented pvalue of the test statistic above 0.05 For all estimated models.

Before evaluating the results of the variables of interest, a general analysis of the results of the other variables of control inserted in the general model, as follows.

Population and investment (capital accumulation), on the one hand, capture the effect of factor driven growth, according to the traditional trade literature. On the other hand, the proxy for capital ratio, Gross Fixed Capital Formation as a percentage of GDP, also expresses the physical production capacity of the economy.

\footnotetext{
${ }^{18}$ In other words, the coefficients were also estimated by means of the regression models by fixed effects and variable effects, that is, by means of static panel. However, due to the strong presence of endogenous explanatory variables, we chose to report only the results estimated through dynamic panel. In addition, the present application of the dynamic models also used the xtabond 2 routine in Stata, developed by Roodman (2009), with small, orthog, twostep and robust options. The first of these options allows the use of more suitable statistics for small samples. Similarly, the orthog option defines that the differentiation operation of the level equation is done with the orthogonal differentiation: subtracting from the values of the observations the values of the average of the future observations taking advantage of the information of the sample. The robust option points to the estimation of standard errors with bias correction by heteroscedasticity, as pointed out and developed by Windmeijer (2005). To reduce the number of instruments, we used few lags as instruments instead of all available lags or the Collapse command in Stata. Since, firstly, the laglimits command was chosen, because the collapse imposes a greater reduction in the number of instruments.

${ }^{19}$ Especially for the variable Human Capital, whose database does not present values for 2011.

${ }^{20}$ In order to deal with this problem of proliferation of instruments, in all estimations the laglimits and collapse commands were used, and only in cases in which the laglimits was not sufficient to reduce the number of instruments in relation to the number of countries of the sample used The collapse command.
} 
In all the estimated models, the population variable, in logarithmic terms, presented negative sign and high coefficients, with statistical significance in 11 of the 16 models estimated in the total. Therefore, the proxy for the growth rate of labor factor countered the traditional notes on its positive effect for economic growth. However, this is an imperfect measure of labor productivity and its negative effect may be related to the economic and social structure of countries associated with an unequal distribution of wealth and income; Given that the dependent variable is the per capita GDP growth rate (measure closest to economic development) and not the aggregate GDP. The investment showed a positive signal in all the estimated models, demonstrating significant in three models via Difference GMM and in five via GMM System. Therefore, as expected, this variable is fundamental to the growth strategies of the countries in the recent period, both by their multiplier mechanism of income and by the effect that the physical productive capacity exerts on the international competitiveness.

The variable government expenditures showed negative sign and significance in all the models estimated by GMM Difference, showing that the "size" of the government negatively affected the performance of the sample countries in the period 2003-2011. Already by means of the System estimator, only showed the expected signal in the models (4) to (8) and significance in the model (7). The growth rate of exports also showed an expected signal and high coefficients in both estimates. In the models estimated by Difference, this variable was significant in seven models and by means of the System presented a significance in only three, which shows that exports have a multiplier effect on the income growth of the economies analyzed (coefficients greater than unity).

This same result appears for the human capital proxy, which proved to be the most relevant for the determination of positive effects on growth in most of the estimated models. This variable is also expressed in logarithmic terms, thus highlighting the high elasticity found: a $1 \%$ increase in the percentage of highly skilled workers increases GDP by approximately $1 \%$ to $40 \%$ depending on the estimated models. In comparison with the proxy result for the labor factor, it is explicit that one of the main sources of competitiveness of the countries is not the abundance of labor, but their productivity associated with qualification and education.

The inflation rate showed a negative sign in most of the models (12 in all), but statistical significance in only 4, being the highest significance evidenced in model 4 estimated by System GMM. Thus, it is believed that an increase in inflation increases economic instability and reduces competitiveness through prices (costs) which leads to a negative relationship with growth, but not as significant. It should be noted that such a price index is very volatile and affected by a series of other variables not explicit in the general model, such as the exchange rate differential.

With regard to the initial per capita GDP, it was only possible to obtain the coefficients through the System GMM method, since the Difference GMM estimator omitted this variable automatically due to the presence of collinearity. This variable presented a negative coefficient and close to zero in seven of the eight models presented, as expected, but only statistically significant in model 3 . Therefore, the evidence for the selected sample does not completely confirm the hypothesis of neoclassical model income convergence.

The coefficients estimated for institutional proxy (regulatory quality) were also not statistically significant. In addition, while in GMM Difference estimations, this variable had a negative coefficient in seven of the eight models, in the estimation by System GMM the signal was positive in all models, according to the expected.

With regard to the variables of interest and with the two main hypotheses raised in this article we can draw several conclusions. First, the hypothesis 1 is completely confirmed by means of the two estimates (Difference and System GMM) both when using the VS indicator and when using the GVC_participation indicator.

- The VS index, which represents the imported intermediate content necessary for the production of export-oriented products, which is a measure of the degree of vertical specialization of economies or of international fragmentation of production, presented a positive and significant coefficient in both estimates. In model 1 estimated via Difference GMM, the coefficient was 0.909 and in the model estimated by System GMM the coefficient was 0.593 , both statistically significant at $1 \%$. 
- The GVC_participation index, which takes into account both the forward participation in the GVC and the backward participation, presented a coefficient lower than the VS index, but also positive and significant (0.462 with statistical significance at $10 \%$ in model 2, via Diff 0.462 signifier To $5 \%)$.

Thus, in fact, the thesis is that the international fragmentation of production and the insertion in GVC are new sources of competitiveness with positive effects for the economic growth of the countries in the recent period, as pointed out by the international organizations of commerce and labor of Foster et al. (2013). Second, the hypothesis 2 is confirmed in part on the importance of the standards of specialization in high technology sectors associated with upstream positions in GVC.

- The GVC_position index presented high coefficients and negative sign in both estimates (-3.399 and -11.959), but only significance in model 2 estimated by System GMM, at 10\%. Since this index is formed by the ratio between measures VS1 (forward participation) and VS (backward participation), it means that larger indices represent more upstream positions in the GVC, given jointly by higher VS1 and smaller VS. Thus, for the selected sample, upstream positions do not guarantee growth benefits from GVC insertion. On the contrary, they are associated with negative impacts on countries' economic performance.

- This negative impact of the GVC upstream position may be associated with the nature of the activities carried out upstream and downstream. This can be seen by estimating models 6,7 and 8, which introduces the GVC_position index calculated for three subsets of economic activities: primary sectors and low-tech manufactures (expressed as GVC_position LT), medium and high technology manufactures ( GVC_position HT) and services (GVC_position S). Although they did not present statistical significance in the models estimated by Diff., In all of them, these variables presented the expected signal.

- The GVC_position LT index showed, as expected, negative and non-significant coefficients in the two estimates (-2.559 and -3.015). The coefficient of the variable GVC_position HT presents values of 13,302 and 27,973, with the System GMM estimator being significant at 10\%; And the coefficient of the variable GVC_position S ranging from 0.405 to 2.340 , with the latter significant at $5 \%$.

Therefore, it has been shown that upstream GVC positions only positively affect the economic performance of countries when associated with the higher value added activities present at the "smiling curve" ends and the production of intermediates with higher technological content destined for re-export.

As already mentioned, the GVC_position index is a joint measure of the importation of exportoriented intermediaries with the export of intermediaries for re-export. Hence the higher the GVC_position HT index, the more countries are exporting high-tech intermediates intended for intermediate demand relative to the imports of intermediaries needed to produce their goods to be exported. According to the estimates, this has a positive effect on the growth of the countries in this sample. Similarly, the service sector, which in view of its structural characteristics tends to have a higher share of VS1 than VS also has a positive effect on growth. This confirms, for example, the GVC approach ${ }^{21}$ notes, which demonstrate in case studies that the greater the variety of services within a larger country is its flexibility to engage in a greater number and diversity of GVC and to derive economic benefits from that involvement.

Finally, with respect to models 4 and 5, no evidence has been found to confirm the hypothesis that more sophisticated (in terms of technological content) or more intensive patterns in manufacturing (manufacturing industry) positively impact economic growth.

- The index q presented positive coefficients, but not significant in the two estimates $(17,703$ and 7,588), as well as the variable VAD_Indústria\%, which expresses the ratio domestic value added by the manufacturing industry in exports over total $\operatorname{VAD}(0,354$ and 0,109$)$. That is, the coefficients estimated for the control variables in these two models are very close because of the high correlation these variables have with each other.

\footnotetext{
${ }^{21} \mathrm{~A}$ fundamentally microeconomic approach to analysis formed by sociology and political science scholars who have created the term Global Value Chain and who use this conceptual tool to carry out case studies and understand the development opportunities of emerging economies such as: Gary Gereffi (Duke University), Raphael Kaplinksy (Open University), among others.
} 
A comparison of the significance of these two measures with those related to participation and positioning in GVC also confirms the perception that the new trade configurations have engendered a redefinition of the concept of commercial specialization standard, by which participation in GVC and Place in the chain (place in the chain) gain importance relative to sectoral specialization (as measured by q). That is, the specialization in the production of intermediaries for the global production networks has been more significant than the traditional specialization that considers only final products.

\section{Final Remarks}

The econometric model developed proposes an alternative to the problematic currently discussed about the effects of the new forms of international organization of production on the macroeconomic performance of the countries. Moreover it introduces variables into a general growth model which have never been worked out that way in the seminal literature on trade and economic growth. Therefore, it advances by proposing for the first time to test the impact of different GVC related proxies on a dynamic panel model for 40 countries.

First, there was evidence that only the vertical specialization of production (import of intermediate content destined for export) and participation in GVC ("forward" and "backward" participation together) already provide positive gains in terms of economic growth. Subsequently, it was also verified in an aggregate way that upstream positions in the GVC with, respectively, greater "forward" participation and lower "backward" participation tend to negatively affect the economic growth. Thirdly, it has been shown that there is an increase in the relative importance of the commercial specialization given by the position in the GVC (place in the chain), associated to the technological aspects of the sectors, to the detriment of only the sector-base technological specialization. Therefore, upstream positions in high technology GVC have impacted positively and significantly the growth of the sample countries, while the commercial specialization as a whole (intermediaries and finals) in industrial sectors, or in high-tech sectors (more sophisticated exports) did not show statistical significance in the estimated models. In addition, there is also a positive and significant determination of upstream GVC positions of services on economic growth.

These results suggest statistical and econometric evidence that international fragmentation of production and participation in GVC are new determinants of economic growth rates. In addition, the position in the GVC is also relevant: countries specialized in upstream activities in high technology sectors and services tend to grow more than countries located upstream in primary sectors, since the index of positioning in the GVC has proved to be relevant and positively related to per capita GDP growth when calculated individually for the medium-high and high technology industry and for the services sector.

The change of position in the GVC is not automatic, mainly because integrating with the GVC usually implies, by definition, an abrupt increase in the use of foreign imported inputs, and requires knowledge absorption and cumulative capacities along the chains, as well as instruments of governance. Therefore, the models that evaluate the role of position in the GVC developed here are a simplification of our hypothesis that obviously do not capture all the dynamic effects that the participation profile in the GVC can attribute to the growth of the countries, for example, the effect of the different forms of upgrading or as a possible path dependent dependence effect of the chains over time.

In this way, the results presented here are an invitation for future work, aiming to carry out new empirical analyzes with other variables that capture the dynamic effects related to the GVC or with other periods and countries, which can express new stylized facts or specificities. In addition, the relevance of our variables of interest, especially the fragmentation and participation in GVC, demonstrates the need for future work that incorporates mathematically in theoretical models that relate trade and growth, as for example in Keynesian growth models with external restraint or in Neoschumpeterian models of international competitiveness. 


\section{References}

Arellano, M. and Bond, S. (1991). "Some tests of specification for panel data: Monte Carlo evidence and an application to employment equations." Review of Economic Studies, Vol. 58, pp. 277-297.

Baldwin, R. (2013) "Global supply chains: why they emerged, why they matter and where are they going." Elms, D. and Low, P. Global Value Chains in a Changing World. Fung Foundation, Temasek Foundation and World Trade Organization. Geneva, Switzerland, pp. 13-59.

Blundell, R. and S. Bond. (1998) "Initial conditions and moment restrictions in dynamic panel data models." Journal of Econometrics, Vol. 87 No.1, pp. 115-143.

Dalle, D., Fossati, V. and Lavopa, F. (2014) "Industrial Policy and development space; The missing piece in the GVC debate." VOX CEPR's Policy Portal, 13 April, pp. 1-4.

Dedrick, J., .Kraemer, K.L and Linden, G. (2008) "Who Profits From Innovation in Global Value Chains? A Study of the iPod And Notebook PCs." Industrial and Corporate Change, Vol. 19 No. 1, pp. 81-116.

Foster, N., De Vries, G. and Stehrer, R. (2012) "Offshoring and the Skill Structure of Labour Demand”, Working Paper 86, The Vienna Institute for International Economic Studies (wiiw), Viena, June.

Foster, N., Stehrer, R. and Timmer, M. (2013) "International fragmentation of production, trade and growth: Impacts and prospects for EU member states." European Economy. Economic Papers 484, Brussels, Belgium.

Gereffi, G. (1999) "International trade and industrial upgrading in the apparel commodity chain." Journal of international economics, Vol. 48, pp. 37-70.

Gereffi, G., Humphrey, J. and Sturgeon, T. (2005) "The governance of global value chains." Review of International Political Economy, Vol. 12. No. 1, pp. 78-104.

Hummels, D., J. Ishii and YI, K. (2001) “The Nature and Growth of Vertical Specialization in World Trade.” Journal of International Economics Vol. 54, pp. 75-96.

Kaminski, B. and NG, F. (2001) "Trade and production fragmentation: Central European economies in European Union networks of production and marketing." Policy Research Working Paper Series 2611, The World Bank, June.

Kaplinsky, R. and Morris, M. (2002) A Handbook for Value Chain Research. Institute of Development Studies, pp.1-109.

Kawakami, M. and Sturgeon, T.J. (2010) "Global value chains in the electronics industry: was the crisis a window of opportunity for developing countries?” Policy Research Working Papers. World Bank group, September.

Koopman, R, W. Powers, Z. Wang, Usitc and S.Wei. (2010) Give Credit Where Credit Is Due: Tracing Value Added in Global Production Chains. NBER Working 16426, NBER, September.

Koopman, R. Wang W. and Wei, S.J. (2014) Tracing Value-Added and Double Counting in Gross Exports. American Economic Review, Vol. 104, No. 2, pp. 459-94.

Lemoine, F., and Unal-Kesenci, D. (2004) "Assembly trade and technology transfer: The case of China." World Development, Vol. 32, No. 5, pp. 829-850.

OECD (2013) "Interconnected economies: benefiting from global value chains." Synthesis Report, 272p.

OECD-WTO (2012) Trade in Value-Added: Concepts, Methodologies and Challenges, 2012.

Quast, B.A. and Kummritz, V. (2015) “decompr: Global Value Chain decomposition in R.” CTEI Working Papers, vol. 1.

UNCTAD (2013) "Global Value Chains: Investment and Trade for Development.” World Investment Report 2013. United Nations: New York/Geneva, pp.1-264. 


\section{Appendix}

Table I: List of selected variables for the models: Descriptions and Data Sources

\begin{tabular}{|c|c|c|}
\hline Variables & Description & Data base \\
\hline $\begin{array}{l}\text { GDP per capita } \\
\text { Growth }(y)\end{array}$ & $\begin{array}{l}\text { Real GDP growth rate per capita (\%) (Dependent variable) GDP per capita is in } \\
\text { constant } 2005 \text { US\$. }\end{array}$ & WDI (2014) \\
\hline GDP t-1 & Real GDP growth rate per capita lagged over a period (\%) & WDI (2014) \\
\hline GDP initial & Per capita GDP for 2003.It is in constant US \$, 2005. & WDI (2014) \\
\hline VS & $\begin{array}{l}\text { VS index of vertical specialization calculated based on Hummels et al. (2001)-content } \\
\text { imported in exports as a percentage of the total exported. Proxy for international } \\
\text { fragmentation of production. }\end{array}$ & $\begin{array}{l}\text { WIOD (2013) } \\
\text { Our calculation. }\end{array}$ \\
\hline GVC_position & Index of GVC position calculated based on Koopman et al. (2014). & $\begin{array}{l}\text { WIOD (2013) } \\
\text { Our calculation. }\end{array}$ \\
\hline GVC_participation & Index of participation in GVC calculated based on Koopman et al. (2014). & $\begin{array}{l}\text { WIOD (2013) } \\
\text { Our calculation. }\end{array}$ \\
\hline Q & $\begin{array}{l}\text { Index of "quality" or sophistication of the exports calculated on the basis of the formula } \\
\text { (VA1 + VA2) /VAT }\end{array}$ & $\begin{array}{l}\text { WIOD (2013) } \\
\text { Our calculation. }\end{array}$ \\
\hline VAD_Industry\% & $\begin{array}{l}\text { Percentage share of total domestic value added by the manufacturing industry over the } \\
\text { total VAD. }\end{array}$ & $\begin{array}{l}\text { WIOD (2013) } \\
\text { Our calculation. }\end{array}$ \\
\hline GVC_posi_LT & Index of GVC position in low-tech sectors (Primary plus low-tech industry). & $\begin{array}{l}\text { WIOD (2013) } \\
\text { Our calculation. }\end{array}$ \\
\hline GVC_posi_HT & $\begin{array}{l}\text { Position index in GVC in high technology sectors (Medium and high technology } \\
\text { industry). }\end{array}$ & $\begin{array}{l}\text { WIOD (2013) } \\
\text { Our calculation. }\end{array}$ \\
\hline GVC_posi_S & Index of position in GVC in service sectors. & $\begin{array}{l}\text { WIOD (2013) } \\
\text { Our calculation. }\end{array}$ \\
\hline Investment & $\begin{array}{l}\text { Rate of growth of capital or investment given by the proxy 'growth rate of the ratio } \\
\text { Gross Fixed Capital Formation (FBKF) / GDP'. }\end{array}$ & WDI (2014) \\
\hline Population & Labor force growth rate given by the proxy 'population growth rate'. & WDI (2014) \\
\hline Human Capital & $\begin{array}{l}\text { Human Capital - hours worked by people of high qualification as part of total hours } \\
\text { worked, included in the growth equation as natural logarithm. }\end{array}$ & $\begin{array}{l}\text { WIOD (2013) } \\
\text { Our calculation. }\end{array}$ \\
\hline Institutions & $\begin{array}{l}\text { Regulatory Index - Government's ability to formulate and implement sound policies } \\
\text { and regulations that enable and promote private sector development. Index ranges from } \\
-2.5 \text { to } 2.5 \text {. }\end{array}$ & $\begin{array}{l}\text { Worldwide } \\
\text { Governance } \\
\text { Indicators, } \\
\text { (2014) }\end{array}$ \\
\hline Inflation & Inflation rate measured by the Consumer Price Index (annual \%) & WDI (2014) \\
\hline Government & Government spending growth rate (\% of GDP) & WDI (2014) \\
\hline Exports & Gross exports, included in the growth equation in terms of growth rate. & WIOD (2013) \\
\hline year6, year7, year8 & $\begin{array}{l}\text { Dummy variables for years } 2008,2009 \text { and } 2010 \text { - control for the effects of the } \\
\text { international crisis of } 2008 \text {. }\end{array}$ & \\
\hline
\end{tabular}



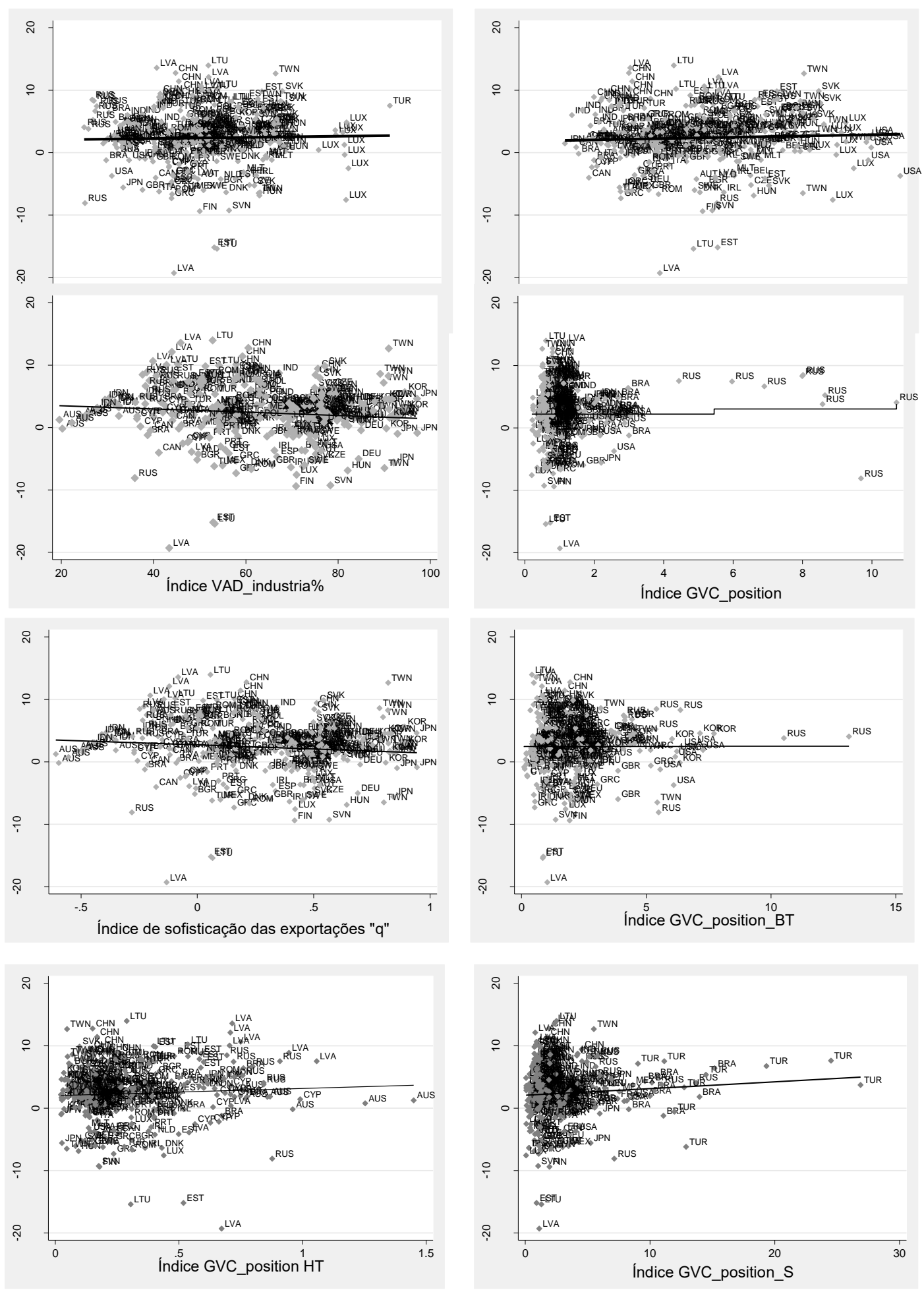

Figure I: Graphs of correlation between interest variables and the per capita GDP growth rate (20032011) 
Table II: Results from panel data estimates using Difference GMM and System GMM. Dependent variable: GDP growth per capita, 2003-2011

\begin{tabular}{|c|c|c|c|c|c|c|c|c|c|c|c|c|c|c|c|c|}
\hline \multirow[b]{2}{*}{ Models } & \multicolumn{8}{|c|}{ Difference GMM } & \multicolumn{8}{|c|}{ System GMM } \\
\hline & 1 & 2 & 3 & 4 & 5 & 6 & 7 & 8 & 1 & 2 & 3 & 4 & 5 & 6 & 7 & 8 \\
\hline GDP t-1 & $\begin{array}{c}0.411 \\
(0.420)\end{array}$ & $\begin{array}{l}-0.042 \\
(0.340)\end{array}$ & $\begin{array}{c}0.077 \\
(0.686)\end{array}$ & $\begin{array}{c}0.620 \\
(0.581)\end{array}$ & $\begin{array}{c}0.620 \\
(0.581)\end{array}$ & $\begin{array}{c}0.175 \\
(0.741)\end{array}$ & $\begin{array}{c}0.132 \\
(1.044)\end{array}$ & $\begin{array}{c}0.623 \\
(0.840)\end{array}$ & $\begin{array}{l}-0.299 \\
(0.261)\end{array}$ & $\begin{array}{l}-0.329 \\
(0.246)\end{array}$ & $\begin{array}{l}-0.117 \\
(0.375)\end{array}$ & $\begin{array}{l}-0.219 \\
(0.372)\end{array}$ & $\begin{array}{l}-0.217 \\
(0.316)\end{array}$ & $\begin{array}{l}-0.410 \\
(0.339)\end{array}$ & $\begin{array}{l}-0.432 \\
(0.626)\end{array}$ & $\begin{array}{l}0.157 \\
(0.529)\end{array}$ \\
\hline GDP initial & - & - & - & - & - & - & - & - & $\begin{array}{l}-0.001 \\
(0.001)\end{array}$ & $\begin{array}{l}-0.001 \\
(0.001)\end{array}$ & $\begin{array}{c}-0,002 * * \\
(0.000)\end{array}$ & $\begin{array}{l}-0.001 \\
(0.001)\end{array}$ & $\begin{array}{l}-0.001 \\
(0.001)\end{array}$ & $\begin{array}{l}-0.001 \\
(0.000)\end{array}$ & $\begin{array}{l}0.001 \\
(0.001)\end{array}$ & $\begin{array}{l}-0.001 \\
(0.001)\end{array}$ \\
\hline Investment & $\begin{array}{c}1,036^{* *} \\
(0.482)\end{array}$ & $\begin{array}{l}0.415 \\
(0.464)\end{array}$ & $\begin{array}{c}1,662 * * \\
(0.671)\end{array}$ & $\begin{array}{l}0.667 \\
(0.612)\end{array}$ & $\begin{array}{c}0.667 \\
(0.612)\end{array}$ & $\begin{array}{l}2,364^{*} \\
(1.224)\end{array}$ & $\begin{array}{c}2.187 \\
(1.598)\end{array}$ & $\begin{array}{c}1.619 \\
(1.164)\end{array}$ & $\begin{array}{c}0.618 \\
(0.726)\end{array}$ & $\begin{array}{l}0,743^{*} \\
(0.390)\end{array}$ & $\begin{array}{l}1,322^{*} \\
(0.771)\end{array}$ & $\begin{array}{c}0,914 * * * \\
(0.313)\end{array}$ & $\begin{array}{l}0.916 \\
(0.566)\end{array}$ & $\begin{array}{l}0.743 \\
(0.833)\end{array}$ & $\begin{array}{l}1,357 * \\
(0.799)\end{array}$ & $\begin{array}{c}1,094 * * \\
(0.468)\end{array}$ \\
\hline Population & $\begin{array}{c}-7,181 * * \\
(3.283)\end{array}$ & $\begin{array}{c}-11,648 * * \\
(5.442)\end{array}$ & $\begin{array}{c}-12,157 * * \\
(5.228)\end{array}$ & $\begin{array}{c}-10,471 * \\
(5.926)\end{array}$ & $\begin{array}{c}-10,471 * \\
(5.926)\end{array}$ & $\begin{array}{l}-13.609 \\
(10.773)\end{array}$ & $\begin{array}{c}-10.085 \\
(9.352)\end{array}$ & $\begin{array}{l}-9.875 \\
(7.153)\end{array}$ & $\begin{array}{c}-13,295 * * * \\
(4.270)\end{array}$ & $\begin{array}{c}-11,781 * * \\
(4.602)\end{array}$ & $\begin{array}{c}-12,012 * \\
(6.774)\end{array}$ & $\begin{array}{l}-7.898 \\
(6.180)\end{array}$ & $\begin{array}{c}-7,654^{*} \\
(4.362)\end{array}$ & $\begin{array}{c}-16,723^{* *} \\
(7.854)\end{array}$ & $\begin{array}{l}-7.287 \\
(5.640)\end{array}$ & $\begin{array}{c}-14,314 * * \\
(5.756)\end{array}$ \\
\hline Human Capital & $\begin{array}{l}9.429 \\
(6.045)\end{array}$ & $\begin{array}{c}0.763 \\
(14.117)\end{array}$ & $\begin{array}{c}12.671 \\
(11.279)\end{array}$ & $\begin{array}{c}21,947 * * \\
(8.601)\end{array}$ & $\begin{array}{c}21,947 * * \\
(8.601)\end{array}$ & $\begin{array}{c}24,163^{*} \\
(14.037)\end{array}$ & $\begin{array}{c}25,261 * \\
(14.288)\end{array}$ & $\begin{array}{c}24.285 \\
(14.483)\end{array}$ & $\begin{array}{l}17,342 * \\
(10.236)\end{array}$ & $\begin{array}{c}13,512 * \\
(7.260)\end{array}$ & $\begin{array}{c}28,218 * * \\
(10.763)\end{array}$ & $\begin{array}{c}32,646 * * \\
(15.422)\end{array}$ & $\begin{array}{l}26.635 \\
(2.349)\end{array}$ & $\begin{array}{c}15,352 * * \\
(7.430)\end{array}$ & $\begin{array}{c}10.454 \\
(16.506)\end{array}$ & $\begin{array}{c}42,031 * * \\
(19.237)\end{array}$ \\
\hline Instituitions & $\begin{array}{l}6.707 \\
(8.096)\end{array}$ & $\begin{array}{l}-1.912 \\
(6.717)\end{array}$ & $\begin{array}{c}-14.613 \\
(9.256)\end{array}$ & $\begin{array}{l}-7.903 \\
(6.023)\end{array}$ & $\begin{array}{l}-7.903 \\
(6.023)\end{array}$ & $\begin{array}{l}-2.537 \\
(11.131)\end{array}$ & $\begin{array}{l}-10.497 \\
(10.873)\end{array}$ & $\begin{array}{c}-6.762 \\
(10.043)\end{array}$ & $\begin{array}{l}6.556 \\
(6.208)\end{array}$ & $\begin{array}{c}3.456 \\
(4.459)\end{array}$ & $\begin{array}{l}7,265^{*} \\
(3.729)\end{array}$ & $\begin{array}{l}1.289 \\
(6.283)\end{array}$ & $\begin{array}{l}-0.165 \\
(5.583)\end{array}$ & $\begin{array}{l}1.874 \\
(5.804)\end{array}$ & $\begin{array}{c}-10.983 \\
(9.374)\end{array}$ & $\begin{array}{c}6.158 \\
(11.371)\end{array}$ \\
\hline Government & $\begin{array}{c}-1,400 * \\
(0.830)\end{array}$ & $\begin{array}{c}-2,966 * * * \\
(0.794)\end{array}$ & $\begin{array}{c}-2,701 * * * \\
(0.955)\end{array}$ & $\begin{array}{c}-3,373 * * * \\
(1.035)\end{array}$ & $\begin{array}{c}-3,373 * * * \\
(1.035)\end{array}$ & $\begin{array}{c}-2,614 * * \\
(1.265)\end{array}$ & $\begin{array}{c}-2,883 * * \\
(1.322)\end{array}$ & $\begin{array}{c}-2,487 * * \\
(1.070)\end{array}$ & $\begin{array}{c}0.293 \\
(0.625)\end{array}$ & $\begin{array}{l}0.363 \\
(0.593)\end{array}$ & $\begin{array}{l}0.616 \\
(0.735)\end{array}$ & $\begin{array}{l}-0.175 \\
(2.429)\end{array}$ & $\begin{array}{l}-0.167 \\
(0.641)\end{array}$ & $\begin{array}{l}-0.441 \\
(1.232)\end{array}$ & $\begin{array}{c}-3,515^{* * * *} \\
(1.180)\end{array}$ & $\begin{array}{l}-0.815 \\
(1.047)\end{array}$ \\
\hline Inflation & $\begin{array}{c}-0,354^{*} \\
-0.176\end{array}$ & $\begin{array}{l}-0.273 \\
(0.170)\end{array}$ & $\begin{array}{l}0.058 \\
(0.166)\end{array}$ & $\begin{array}{l}-0.101 \\
(0.181)\end{array}$ & $\begin{array}{l}-0.101 \\
(0.181)\end{array}$ & $\begin{array}{l}0.043 \\
(0.248)\end{array}$ & $\begin{array}{l}0.136 \\
(0.364)\end{array}$ & $\begin{array}{l}-0.034 \\
(0.229)\end{array}$ & $\begin{array}{l}-0.344 \\
(0.277)\end{array}$ & $\begin{array}{c}-0,372 * \\
(0.217)\end{array}$ & $\begin{array}{l}-0.14 \\
(0.314)\end{array}$ & $\begin{array}{c}-0,586 * * \\
(0.234)\end{array}$ & $\begin{array}{c}-0,558^{*} \\
(0.310)\end{array}$ & $\begin{array}{l}-0.342 \\
(0.320)\end{array}$ & $\begin{array}{l}0.075 \\
(0.223)\end{array}$ & $\begin{array}{l}-0.196 \\
(0.524)\end{array}$ \\
\hline Exports & $\begin{array}{c}11,767 * * * \\
(3.349)\end{array}$ & $\begin{array}{l}6,826^{*} \\
(3.524)\end{array}$ & $\begin{array}{l}6.810 \\
(4.585)\end{array}$ & $\begin{array}{c}9,394 * * * \\
(3.255)\end{array}$ & $\begin{array}{c}9,394 * * * \\
(3.255)\end{array}$ & $\begin{array}{c}12,366^{* * *} \\
(6.009)\end{array}$ & $\begin{array}{c}10,559 * \\
(5.625)\end{array}$ & $\begin{array}{c}10,996^{*} \\
(5.643)\end{array}$ & $\begin{array}{l}5.565 \\
(3.803)\end{array}$ & $\begin{array}{c}5,690 * * \\
(2.524)\end{array}$ & $\begin{array}{c}6,894 * * \\
(3.114)\end{array}$ & $\begin{array}{l}8.009 \\
(6.927)\end{array}$ & $\begin{array}{c}6.866 \\
(8.729)\end{array}$ & $\begin{array}{l}1.904 \\
(2.276)\end{array}$ & $\begin{array}{c}0.962 \\
(5.343)\end{array}$ & $\begin{array}{l}9,526^{*} \\
(5.349)\end{array}$ \\
\hline VS & $\begin{array}{c}0,909 * * * \\
(0.273)\end{array}$ & & & & & & & & $\begin{array}{c}0,593 * * * \\
(0.199)\end{array}$ & & & & & & & \\
\hline GVC_participation & & $\begin{array}{l}0,462^{*} \\
(0.234)\end{array}$ & & & & & & & & $\begin{array}{c}0,422 * * \\
(0.181)\end{array}$ & & & & & & \\
\hline GVC_postion & & & $\begin{array}{l}-3.399 \\
(3.008)\end{array}$ & & & & & & & & $\begin{array}{c}-11,959 * \\
(6.479)\end{array}$ & & & & & \\
\hline "q" index & & & & $\begin{array}{l}17.703 \\
(29.624)\end{array}$ & & & & & & & & $\begin{array}{c}7.588 \\
(27.569)\end{array}$ & & & & \\
\hline VAD_Industry $\%$ & & & & & $\begin{array}{l}0.354 \\
(0.592)\end{array}$ & & & & & & & & $\begin{array}{c}0.109 \\
(0.499)\end{array}$ & & & \\
\hline GVC_position LT & & & & & & $\begin{array}{l}-2.559 \\
(2.328)\end{array}$ & & & & & & & & $\begin{array}{l}-3.015 \\
(3.145)\end{array}$ & & \\
\hline GVC_position HT & & & & & & & $\begin{array}{c}13.302 \\
(29.206)\end{array}$ & & & & & & & & $\begin{array}{c}27,973 * \\
(16.383)\end{array}$ & \\
\hline GVC_position S & & & & & & & & $\begin{array}{c}0.405 \\
(1.714)\end{array}$ & & & & & & & & $\begin{array}{c}2,340 * * \\
(1.130)\end{array}$ \\
\hline $\mathrm{AR}(2)$ & 0.474 & 0.222 & 0.317 & 0.215 & 0.215 & 0.628 & 0.934 & 0.465 & 0.847 & 0.835 & 0.387 & 0.809 & 0.683 & 0.241 & 0.328 & 0.437 \\
\hline Hansen test & 0.208 & 0.500 & 0.359 & 0.420 & 0.420 & 0.096 & 0.141 & 0.153 & 0.318 & 0.191 & 0.752 & 0.114 & 0.037 & 0.557 & 0.218 & 0.269 \\
\hline Diff, Hansen Test & - & - & - & - & - & - & - & - & 0.974 & 0.975 & 0.621 & 0.724 & 0.932 & 0.642 & 0.249 & 0.556 \\
\hline $\mathrm{N}^{\circ}$ of instruments & 18 & 20 & 21 & 21 & 21 & 16 & 16 & 16 & 24 & 24 & 24 & 26 & 24 & 24 & 24 & 24 \\
\hline
\end{tabular}

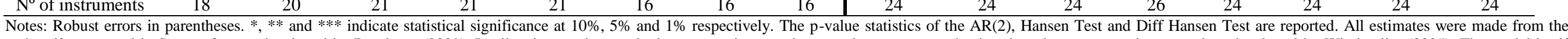

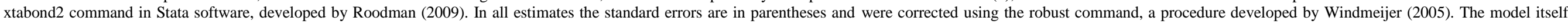

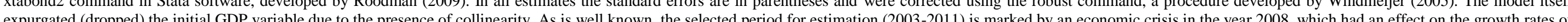

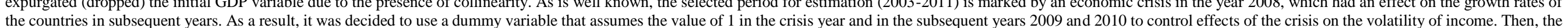
estimated models include time dummies for the years of the crisis and post-crisis - 2008, 2009 and 2010 not reported. 